\title{
KAJIAN EUFEMIA DAN DISFEMIA DALAM BERITA POJOK KAMPUNG JTV
}

\author{
Latif Nur Hasan \\ Universitas Negeri Surabaya \\ latifhasan@unesa.ac.id
}

\begin{abstract}
Abstrak
Manusia berbahasa akan melakukan pertimbangan-pertimbangan tertentu. Pertimbangan tersebut bisa dengan pertimbangan kesopanan, penghormatan, penegasan, rasa jengkel dan lain sebagainya. Redaksi sebuah berita Pojok Kampung di stasiun televisi JTV-pun juga melakukan pertimbanganpertimbangan tersebut. Pertimbangan-pertimbangan tersebut memunculkan penggunaan eufemia dan disfemia yang kadang terkesan tidak berterima.

Penggunaan eufemia dan disfemia dalam berita Pojok Kampung JTV ditemukan berupa kata dan frasa. Data-data yang didapatkan diperoleh kesimpulan bahwa ketika kata tersebut tidak pantas/kasar diucapkan akan diganti dengan kata yang lebih pantas/halus (eufemia). Sebaliknya jika kata kasar/tidak pantas tersebut memang pantas digunakan untuk sesuatu yang dibicarakan, maka kata kasar yang akan dipilih (disfemia). Makna kata yang digantikan dari eufemia dan disfemia bukanlah makna kata atau makna ujaran, melainkan nilai rasa. Makna ujaran dipertahankan tetap. Eufemia digunakan untuk; menyamarkan yang dianggap tabu; memberi penghargaan atau penghormatan terhadap yang dibicarakan. Sedangkan disfemia digunakan untuk; menunjukkan sikap tidak suka, tidak ramah, atau jengkel; memberikan penekanan yang kuat pada suatu tindakan dan nilai rasa kasar terkadang tidak terasa bila digunakan untuk memberi penekanan kuat.
\end{abstract}

Kata kunci: eufimia, disfemia, berita Pojok Kampung

\begin{abstract}
When humans speak, they will consider a language considerations. Such considerations can be considered politeness, respect, affirmation, annoyance, and so forth. Pojok Kampung news editor of JTV television station do such considerations. These considerations led to the use of Eufemia and disfemia that sometimes seem unacceptable.

Uses of Eufemia and disfemia in Pojok Kampung news JTV, found in the form of words and phrases. The data obtained is concluded that when the word is inappropriate / rough pronounced will be replaced with more appropriate words/smooth (Eufemia). Conversely, if the word rude/inappropriate it deserves used for the matters discussed, the rant will be selected (disfemia). Meaning of words that were replaced from Eufemia and disfemia not the meaning of words or meanings of speech, but a sense of value. Meaning of speech is kept constant. Eufemia is used for; disguise taboo; reward or respect for the discussion. While disfemia used to; shows the attitude of dislike, unfriendly, or annoyed; giving a strong emphasis on action and values sometimes feels rough sense when used to give a stronger emphasis.
\end{abstract}

Keywords: eufimia, disfemia, Pojok Kampung news 


\section{PENDAHULUAN}

Ketika seseorang berbahasa, pastilah memertimbangkan pilihan bahasa yang digunakan. Jika seseorang merasa tidak pantas atau tidak tega untuk mengucapkan kata tersebut, kata tersebut tidak diucapkan. Bahkan jika seseorang merasa pantas dan tega untuk mengucapkan kata tersebut maka kata itu akan diucapkan. Apabila merasa kurang pantas, akan digantikan dengan kata lain yang lebih halus, begitupula sebaliknya. Makna yang ditimbulkan sama hanya saja nilai rasa yang berbeda.

Pertimbangan-pertimbangan tersebut juga dilakukan dalam pemilihan kata dalam redaksi sebuah berita. Ketika berita tersebut membicarakan hal yang dianggap tabu atau tidak pantas diucapkan, maka redaksi akan memilih kata yang lain untuk menghaluskan. Begitu juga sebaliknya ketika berita tersebut membicarakan hal yang tidak menyenangkan, tidak baik atau bahkan menyebalkan, redaksi akan memilih kata yang lebih kasar untuk mempertegas. Pertimbangan-pertimbangan tersebut merupakan hal yang lumrah dalam redaksi sebuah berita.

Selain dengan pertimbangan-pertimbangan tersebut, pemberitaan di sebuah stasiun televisi pada umumnya memiliki kekhasan bahasa dalam menyampaikan informasi. Salah satu kekhasan tersebut adalah adanya pemakaian eufemia dan disfemia. Akan tetapi, pemakaian eufemia dan disfemia tersebut dapat menyebabkan ketidaklaziman makna. Seperti pada pemberitaan dalam program Pojok Kampung JTV.

Pemberitaan dalam Pojok Kampung JTV, memiliki kesan kasar bagi beberapa kalangan masyarakat. Hal ini dikarenakan bahasanya yang lugas dan blak-blakan. Sebenarnya hal tersebut sudah sesuai dengan salah satu sarat bahasa dalam pers yaitu lugas. Tetapi jika dikaji lebih dalam, penggunaan kata-kata lugas, blak-blakan dan kasar tersebut memanglah sudah mengalami pertimbanganpertimbangan. Jika membicarakan hal yang baik, pilihan kata yang akan digunakan adalah kata yang berasa halus begitu juga sebaliknya.

Sehingga pertimbangan kepantasan atau ketegaan ketika bahasa tersebut diucapkan atau tidak memunculkan prinsip dari makna eufemia dan disfemia. Dengan pertimbangan kepantasan dan ketegaan tersebut membuat pemilihan dan penggantian kata yang dirasa sesuai. Banyaknya pilihan dan penggantian kata yang dilakukan dalam Pojok Kampung JTV, Maka dalam tulisan ini dibahas mengenai eufemia dan disfemia dalam berita Pojok Kampung JTV.

\section{HASIL PENELITIAN DAN PEMBAHASAN}

Jika berbicara tentang sopan atau tidak sopan, pantas atau tidak pantasnya sebuah kata itu dipilih, maka yang timbul adalah konsep eufemia dan disfemia. Pembahasan ini, eufemia dan disfemia dalam berita Pojok Kampung tersebut akan dikelompokkan menjadi dua jenis yaitu eufemia dan disfemia yang berupa kata dan berupa frasa.

\section{Eufemia}

Menurut Mustansyir (1988:41), "Eufemia yaitu pemakaian suatu ungkapan yang lembut, samar atau berputar-putar untuk mengganti suatu presisi yang kasar atau suatu kebenaran yang kurang enak". Ada kata kunci dari pengertian tersebut. Kata kunci tersebut adalah lembut/samar/berputar-putar, menggantikan kata kasar. Bisa diartikan bahwa penghalusan atau Eufemia tersebut adalah 
penggantian suatu ujaran yang bernilai rasa netral atau kasar dengan ujaran lain yang mempunyai makna sama tapi dianggap mempunyai nilai rasa lebih halus. Makna ujarannya sama, hanya saja diungkapkan dengan kata yang bernilai rasa lebih halus.

Dengan kata lain Eufemia adalah penghalusan sebuah bahasa yang dirasa kasar. Orang akan mengucapkan kata-kata tersebut jika tidak atau kurang tega jika diucapkan dengan apa adanya. Eufemia ini sangat cocok dengan budaya orang Jawa yang memiliki tingkat sopan santun yang tinggi. Terbukti dengan adanya tingkatan berbahasa dalam bahasa Jawa. Maka dalam berita Pojok Kampung JTV juga banyak digunakan kata atau frasa yang lebih bermaksud menghaluskan.

\section{a) Eufemia Berupa Kata}

(1) "Sementara iku Edi Purnomo Camat Benowo ngincim jange nutup wisma nek kebukti akeh balon lara IMS." (PK Des, 3)

'Sementara itu Edi Purnomo Camat Benowo mengancam akan menutup wisma jika terbukti banyak PSK yang terjangkit IMS.'

Pada kutipan (1) terdapat kata 'balon'. Kata 'balon' merupakan kata benda.Dalam hal ini 'balon' tidak dimaknai sebagai sebuah mainan dari karet yang bisa diisi udara sebanyak apapun masih cukup dan wujudnya lonjong, melainkan dimaknai sebagai kata untuk sebuah pekerjaan menjual dirinya atau melacur yang biasanya disebut PSK.

Kata 'balon' terbentuk karena masih kasarnya kata PSK, Pelacur, begenggek, dan lonthe. Walaupun pekerjaan tersebut termasuk dalam pekerjaan yang hina, tetapi supaya rasa kasar tersebut tidak terasa, maka diganti dengan kata 'balon'. Jika dikatakan 'balon' walaupun orang akan berpikir bahwa yang dimaksud 'balon' adalah pelacur, tetapi makna kasar pelacur sudah sedikit disembunyikan atau dihaluskan. Apalagi kata 'balon' ini digunakan di berita Pojok Kampung JTV yang ditonton oleh berbagai kalangan masyarakat baik muda, tua miskin, dan anak-anak. Sehingga yang terjadi di sini adalah penggantian kata yang dianggap bermakna sama, tetapi rasa yang ditimbulkan berbeda yaitu lebih halus.

Dari data di atas, telah jelas bahwa kata 'balon' dapat digunakan untuk menghaluskan kata-kata yang bermakna hampir sama yaitu antara lain kata Pelacur, PSK, begenggek, dan lonthe. Dalam penuturan bahasa utamanya bahasa Jawa, hal-hal yang kasar atau tidak sopan sangat dihindari. Karena dalam bahasa Jawa sangat memertimbangkan aspek kesopanan dari penutur terhadap petutur.

Keterhalusan kata 'balon' dapat dilihat jika kata-kata lainnya digunakan untuk menggantikan kata-kata tersebut. Seperti pada tuturan kalimat 'Sawise ditinggal bojone, Erna saiki mbalon'. Kata 'mbalon' bermakna melacurkan diri. Bedakan dengan tuturan kalimat ini 'sawise ditinggal bojone, Erna nglonthe'. Kata 'Nglonthe'juga bermakna melacurkan diri. Keduanya bermakna sama, tetapi keduanya memiliki rasa yang berbeda.

(2) "Si mbah teka Bondowoso tega mentala ngipik-ngipik putu'e ndhuk gerbong sepur sing ngemot tebu." (PK Des, 3)

'Kakek dari Bondowoso tega mencabuli cucunya di gerbong kereta yang mengangkut tebu.'

Banyak sekali yang dianggap tabu atau tidak pantas diucapkan secara terang-terangan dalam budaya Jawa. Apalagi yang berhubungan dengan jenis 
kelamin laki-laki dan perempuan. Semua serba tabu. Maka dari itu, untuk memberitakan berita yang sejenis itu, maka akan disesuaikan supaya menjadi kata yang pas diucapkan dan tidak lagi tabu. Setidaknya berkurang ketabuannya.

Seperti pada kutipan (2) terdapat kata 'ngipik-ipik'. Kata tersebut merupakan kata kerja. Kata tersebut termasuk kata yang khusus digunakan di Pojok Kampung. Kata 'ngipik-ipik' digunakan untuk menggambarkan tindakan berhubungan badan antara laki-laki da perempuan dengan cara paksa. Tetapi berhubungan badannya tidak sampai melakukan penetrasi. Dalam bahasa Indonesia dikenal dengan istilah 'mencabuli'.

Untuk menggambarkan tindakan yang sangat tabu tersebut maka diwujudkan atau digantikan dengan kata yang tidak tabu lainnya. Namun apa yang ingin disampaikan tetap dapat diterima oleh penerima berita. Kata 'nyabuli' dan 'ngipik-ipik' memiliki makna yang hampir sama yaitu melakukan pemaksaan seksual terhadap seseorang, tetapi rasa yang ditimbulkan kata 'ngipik-ipik' lebih halus.

(3)“Guru SMA Negeri 1 Pakong Kabupaten Pamekasan mau isuk digerebek warga kelurahan pajagalan sumenep polae konangan hohohihe ambek bojo'e uwong nang kamar kosong buri'e kos-kosan." (PK Des, 2)

'Guru SMA N 1 Pakong Pamekasan tadi pagi digerbek warga kelurahan

Pajagalan Sumenep karena tertangkap basah melakukan hubungan intim dengan istri orang di kamar kosong belakang kos-kosan.'

Adanya eufemia juga terlihat pada kutipan (3) yaitu kata 'hohohihe'. Secara leksikal, kata tersebut tidak bermakna. Tetapi dalam hal ini kata 'hohohihe' digunakan untuk menggambarkan perilaku hubungan intim antara laki-laki dan perempuan. Tetapi kata tersebut digunakan untuk menggambarkan tindakan hubungan intim dengan tidak semestinya atau bisa disebut bertindak selingkuh.

Maka untuk mengurangi rasa tabu tersebut dipilih dengan kata 'hohohihe'. Jika kata 'hohohihe' tersebut diganti dengan 'kelon', seperti pada kalimat berikut 'polae konangan kelon karo bojo'e wong'. Kata 'hohohihe' dan 'kelon' memiliki makna yang hampir sama, hanya saja rasa yang ditimbulkan lebih halus kata 'hohohihe'. Bisa saja kata tersebut diganti dengan 'kikuk-kikuk' dan sebagainya. Penggunaan kata 'hohohihe' bermakna lebih halus atau lebih sopan diucapkan. Karena terkadang rasa tabu tersebut berubah menjadi rasa geli ingin tertawa.

\section{b) Eufemia Berupa Frasa}

Eufemia yang digunakan dalam berita Pojok Kampung JTV tidak hanya berupa kata saja melainkan berupa frasa. Seperti contoh pada kutipan di bawah ini:

(4)"Hla sing paling akeh yaiku Tenaga Kerja Wedok sing buru ae mulih teka luwar negeri." (PK Des, 1)

'Yang paling banyak adalah Tenaga Kerja Wanita yang baru saja pulang dari luar negeri.'

Frasa 'Tenaga Kerja Wedok' pada kutipan (4) merupakan frasa benda yang dalam bahasa Indonesia adalah 'Tenaga Kerja Wanita' yang pada kenyataannya bekerja pada bidang buruh rumah tangga di luar negeri. Kata 'buruh luwar negeri' dirasa kurang halus atau sangat kasar jika digunakan untuk para TKW tersebut. Hal ini dikarenakan TKW menjadi gudang devisa negara. Selain hal tersebut, jika dilihat dari unsur politik, frasa 'buruh luwar negeri' akan lebih merendahkan martabat bangsa Indonesia sendiri. Walaupun di luar negeri hanya menjadi buruh, 
tetapi frase yang digunakan unuk menggantikan 'buruh luar negeri' tersebut adalah frase 'Tenaga Kerja Wedok' karena dirasa lebih halus. Frasa 'Buruh Luwar Negri' dan 'Tenaga Kerja Wedok' tersebut memiliki makna yang hampir sama, tetapi keduanya memiliki rasa yang berbeda ketika diucapkan. Frasa 'Tenaga Kerja Wedok' memberikan rasa yang lebih halus.

Masih ada beberapa penggunaan eufemia dalam berita Pojok Kampung JTV yang dapat dikaji lebih dalam seperti pada kutipan-kutipan di bawah ini:

(5)“Wong pitu sing ngerudhapeksa Ela Rahayu Ningtias 19 taun arek dhusun nambi karang rejo manyar gresik akhire dicekel tim reskrim polsek bungah gresik nang omahe dhewe dhewe." (PK Des, 11)

'Tujuh orang yang memperkosa Ela Rahayu Ning Tyas 19 tahun gadis Dusun Nambi Manyar Gresik akhirnya ditangkap tim reskrim polsek bungah Gresik di rumahnya masing-masing.'

Frasa 'ngrudha peksa' pada kutipan (5) merupakan frasa kerja. Frasa tersebut hampir sama dengan kata 'ngipik-ipik'. Tetapi dalam hal ini tindakannya tidak hanya mendekati berhubungan intim seperti 'ngipik-ipik'. Frasa 'ngrudha peksa' lebih bermakna memaksa orang untuk berhubungan badan, dan sampai melakukan penetrasi. Dalam hal ini yang melakukan tindakan tersebut adalah orang banyak, maka yang lebih tepat digunakan adalah frasa 'ngrudha peksa' daripada 'ngipik-ipik'.

Frasa 'ngrudha peksa' digunakan karena dirasa tidak sopannya kata-kata yang digunakan sebelumnya pada berita Pojok Kulon JTV. Karena kira-kira ketika Pojok Kampung masih baru mengudara, masih sering menggunakan kata kasar untuk menggambarkan tindakan tersebut dengan menyebutkan bagian kelamin laki-laki dan perempuan seperti 'empal brewok' dan 'pistol gombyok'. Jika frasa 'ngrudha peksa' diganti dengan penyebutan alat kelamin tersebut akan semakin kasar seperti pada kalimat 'Wong pitu sing nyudukake pistol gombyok nyang empal brewoke Ela'. Sehingga penggantian pengungkapan tindakan tersebut dengan frasa 'ngrudha peksa' sangat tepat dan memiliki makna lebih halus.

\section{Disfemia}

Berbeda dengan eufimia, disfemia adalah pengasaran. Wijana (1999: 63) mengungkapkan bahwa disfemia merupakan penggunaan bentuk-bentuk kebahasaan yang memiliki nilai rasa tidak sopan atau yang ditabukan. Dari pendapat tersebut, yang memiliki makna kasar adalah bentuk-bentuk kebahasaannya. Seperti kata, frasa atau bahkan kalimat dan wacana.

Chaer juga berpendapat disfemia merupakan pengasaran, yaitu kebalikan dari penghalusan (1995: 145). Disfemia merupakan usaha untuk mengganti katakata yang maknanya halus atau bermakna biasa dengan kata yang maknanya kasar. Usaha atau gejala pengasaran ini biasanya dilakukan orang dalam situasi yang tidak ramah atau untuk menunjukkan kejengkelan

Dari kedua pendapat tersebut di atas dapat disimpulkan, pengasaran atau disfemia adalah penggantian suatu ujaran yang bernuansa makna netral atau halus dengan ujaran lain yang mempunyai makna sama tapi dianggap mempunyai nilai rasa lebih kasar. Makna ujarannya tetap dipertahankan sama, hanya saja diungkapkan dengan kata yang bernilai rasa lebih halus. Secara sederhana disfemia adalah mengganti kata dengan kata yang lebih tidak sopan atau kasar. 
Penggantian ini bisa saja disebabkan karena yang dibicarakan memang pantas diberi kata kasar, atau memang yang dibicarakan adalah hal yang buruk.

\section{a) Disfemia Berupa Kata}

Pemakaian disfemia dalam pemberitaan Pojok Kampung JTV yang berupa kata antara lain seperti di bawah ini:

(6)“Delok anake matek nggelantong yatini sakal cerik-cerik barek jaluk tolong nang tangga kiwa tengene." (PK Des, 3)

Melihat anaknya mati gantung diri Yatini seketika berteriak dan meminta tolong ke tetangga kanan kirinya.'

Tuturan pada kutipan (6) merupakan tuturan yang menggunakan kata yang dikasarkan atau disfemia. Kata 'matek', merupakan kata sifat. 'matek' berarti sudah tidak bernyawa lagi. Dalam tuturan tersebut kata 'matek' digunakan untuk mengabarkan kematian seseorang.

Kata 'matek' digunakan pada kutipan tersebut karena untuk mengungkapkan rasa tidak senangnya dan memberikan penekanan terhadap perbuatan bunuh diri tersebut. Karena dalam persepektif norma agama, norma sosial, norma susila perbuatan tersebut merupakan perbuatan yang tidak diperbolehkan. Bisa saja kata tersebut diganti dengan kata 'mati' tetapi malah apa yang akan disampaikan kurang mengena. Seperti pada kalimat berikut 'ngerti anake mati nggelantong', kata 'mati' dirasa terlalu halus untuk menggambarkan kejengkelan dengan perbuatan gantung diri tersebut. Maka lebih cocok digunakan kata yang tberasa kasar untuk berita tersebut. Kata 'mati' dan 'matek' memilik makna yang sama yaitu telah meninggal dunia, tetapi kata 'matek' memiliki rasa yang lebih kasar. Namun kekasaran rasa tersebut cocok jika digunakan untuk mempertegas ketidaksenangan terhadap tindakan bunuh diri.

(7)“Akibat kedadean iki meh kabeh barang barange warga entek dibadhog geni." (PK Des, 1)

'Akibat dari kejadian tersebut hampir semua barang-barangnya warga habis dimakan api.'

Kata 'dibadhog' pada kutipan (7) tersebut dapat dikatakan sebagai disfemia. Kata tersebut merupakan kata kerja pasif. Yang mana subjek dikenai tindakan. Kata 'dibadhog' berarti dimakan.

Musibah, bagi manusia dapat dikatakan sebagai hal yang tidak disenangi. Tidak ada satu manusiapun yang mengharapkan akan tertimpa musibah. Maka pada tuturan dalam kutipan (7) untuk menyampaikan rasa tidak senangnya dengan peristiwa kebakaran yang telah menghabiskan banyak rumah dan harta benda menggunakan kata yang kasar. Kata tersebut adalah kata 'dibadhog'. Kata tersebut sebenarnya bisa saja diganti dengan kata 'dipangan' seperti pada kalimat berikut 'meh kabeh barang-barange warga dipangan geni', makna yang dihasilkan terasa lebih halus. Padahal yang ingin disampaikan adalah sesuatu yang tidak menyenangkan. Kedua kata yaitu 'dipangan' dan 'daibadhog' memiliki makna yang hampir sama akan tetapi rasa yang ditimbulkan akan berbeda. Yaitu kata 'dibadhog' cenderung lebih kasar dan lebih tepat digunakan pada tuturan mengenai kejengkelan tersebut.

\section{b) Disfemia Berupa Frasa}

Adapun disfemia berupa frasa yang digunakan dalam berita Pojok Kampung JTV adalah sebagai berikut: 
(8)“Sak ben taun wong sing kenek HIV Aids tambah sak taek ndhayak." (PK Des , 1)

'Setiap tahun yang mengidap penyakit HIV Aids bertambah banyak.'

Frasa 'sataek ndhayak' pada kutipan (8) juga termasuk disfemia karena digunakan untuk hal yang tidak disenangi. Frasa 'sataek ndhayak' bermakna melebih-lebihkan tetapi lebih yang kasar. Sebenarnya bisa saja digunakan kata akeh banget, tetapi karena yang diberitakan adalah hal yang tidak disenangi yaitu pengidap HIV Aids, maka penggunaan frasa 'sataek ndhayak' lebih tepat jika dibandingkan dengan 'akeh banget'. Kedua frasa tersebut memiliki makna yang hampir sama yaitu banyak sekali, tetapi rasa kekasarannya yang berbeda. Sehingga sangatlah tepat jika penggantian frasa 'akeh banget' tersebut dengan frasa 'sataek ndhayak' karena untuk menegaskan dan mengungkapkan sesuatu yang buruk atau tidak disenangi.

(9)" Mbok dhewor sing dibedhek umure petang puluhan sing durung weruh sapa jenenge iki matek sek ndhuk kedadean sak marie keterak sepur ndhuk desa bulu terate kecamatan babat kabupaten lamongan esuk mau barek awake ajur mumur." PK Des, 6)

Wanita tak dikenal yang diduga umurnya empat puluh tahunan yang belum diketahui namanya ini tewas di tempat kejadian sesudah tertabrak kerata api di desa Bulu Kecamatan Babat Lamongan pagi tadi dengan tubuh yang hancur.'

Frase 'mbok dhewor' pada kutipan (9) tersebut memiliki makna 'wanita tak dikenal'. Frasa 'mbok dhewor' secara leksikal bermakna wanita yang sudah bersuami yang sudah terlantarkan atau tidak terawat. Frasa 'mbok dhewor' dan 'wanita gak dikenal' memiliki makna yang hampir sama, tetapi memiliki tingkatan rasa yang berbeda. Berhubung dalam hal ini yang diberitakan adalah orang yang tidak dikenal dan sudah dalam keadaan mati maka frasa yang tepat digunakan adalah frasa 'mbok dhewor'. Sehingga menjadi tidak masalah ketika pengungkapan yang kasar tersebut diucapkan dalam redaksi sebuah berita.

\section{SIMPULAN}

Berdasarkan pembahasan yang telah dilakukan pada bab sebelumnya maka dapat disimpulkan bahwa eufemia dan disfemia muncul karena kepantasan atau ketidak pantasan kata tersebut diucapkan, serta kesopanan atau ketidak sopanan kata tersebut diucapkan. Ketika kata tersebut tidak pantas/kasar diucapkan akan diganti dengan kata yang lebih pantas/halus (eufemia). Sebaliknya jika kata kasar/tidak pantas tersebut pantas digunakan untuk sesuatu yang dibicarakan, maka kata kasar yang akan dipilih (disfemia).

Yang berubah dari eufemia dan disfemia bukanlah makna kata atau makna ujaran, melainkan nilai rasa. Makna ujaran dipertahankan tetap.

Eufemia digunakan untuk:

- Menyamarkan yang dianggap tabu

- Memberi penghargaan atau penghormatan terhadap yang dibicarakan

Disfemia digunakan untuk:

- Menunjukkan sikap tidak suka, tidak ramah, atau jengkel

- Memberikan penekanan yang kuat pada suatu tindakan dan nilai rasa kasar terkadang tidak terasa bila digunakan untuk memberi penekanan kuat. 
Jika digambarkan eufemia dan disfemia menjadi seperti di bawah ini:

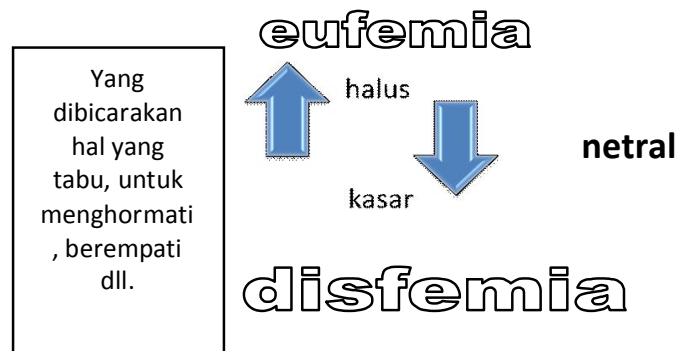
yang dibicarakan hal buruk, hal yang tidak baik dan tidak menyenangkan,

\section{Daftar Pustaka}

Chaer, Abdul. 2009. Pengantar Semantik Bahasa Indonesia. Jakarta: PT. Rineka Cipta

Slametmuljana, Prof. Dr. 1964. Semantik (Ilmu Makna). Djakarta: Djambatan.

Soeparno. 2002. Dasar-dasar Linguistik. Yogyakarta: Tiara Wacana.

Wijana, I. G. P. Semantik. Yogyakarta: Fakultas Sastra Universitas Negeri Yogayakarta. 